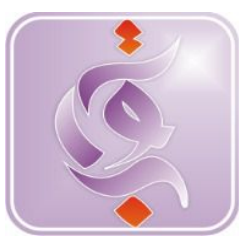

\title{
PELATIHAN KOMUNIKASI INTERPERSONAL UNTUK MENINGKATKAN TEAMWORK KARYAWANPADA PT.X
}

Received: $23^{\text {th }}$ December 2017; Revised: 07th January 2018; Accepted: $23^{\text {th }}$ February 2018

\begin{abstract}
Abdul Azis
UIN Imam Bonjol Padang

Email: azizharly@gmail.com

Alimatus Sahra

Program Magister Psikologi Profesi

Universitas Mercu Buana Yogyakarta

Fakultas Psikologi Universitas Mercu

Buana Yogyakarta

\section{Nur Fachmi Budi S}

Program Magister Psikologi Profesi Universitas Mercu Buana Yogyakarta Fakultas Psikologi Universitas Mercu Buana Yogyakarta
\end{abstract}

\begin{abstract}
Abstrak: Penelitian ini bertujuan untuk mengetahui peningkatan teamwork melalui pelatihan komunikasi interpersonal. Hipotesis penelitian ini yaitu, terdapat perbedaan teamwork pada karyawan antara sebelum dan sesudah diberikan pelatihan komunikasi interpersonal pada kelompok eksperimen, dimana tingat teamwork karyawan setelah diberi pelatihan komunikasi interpersonal lebih tinggi dibanding tingkat teamwork karyawan sebelum diberikan pelatihan komunikasi interpersonal .hipotesis kedua ,terdapat perbedaan tingkat teamwork posttest antara kelompok eksperimen dengan kelompok kontrol. Dimana posttest kelompok teamwork pada eskperimen lebih tinggi dari pada kelompok kontrol. penelitian ini adalah karyawan produksi di PT,X. Karakteristik subjek penelitian ini adalah karyawan yang memiliki tingkat teamwork dan komunikasi interpersonal pada ketegori sangat rendah, rendah dan sedang. Disain yang digunakan adalah pretestpostest Control Group, sedangkan data yang dikumpulkan skala teamwork kemudian dianalisis menggunakan uji Mann Whitney untuk melihat perbedaan skor antara kelompok eksperimen yang diberi pelatihan komuniasi interpersonal dengan kelompok kontrol yang tidak diberikan pelatihan komunikai interpersonal. Selanjutnya dilanjutan uji Wilcoxon untuk melihat skor kelompok eksperimen antara sebelum dan dan sesudah diberikan pelatihan komunikasi interpersonal. Berdasaran hasil uji Mann Whitney ditemunakan $Z=-3,790$ $(\mathrm{p}<0,01)$, artinya ada perbedaan skor kelompok eksperimen yang diberikan pelatihan dengan kelompok kontrol yang tidak diberi pelatihan. Berdasarkan hasil uji Wilcoxon ditemukan ada perbdaan antara skor antara teamwork karyawan kelompok eksperimen antara sebelum dan sesudah diberikan pelatihan komunikai interpersonal dengan $Z=-3,827(p<0,01)$.
\end{abstract}

Kata Kunci : Pelatihan Komunikasi Interpesonal, Teamwork Karyawan

\section{PENDAHULUAN}

Teamwork menjadi sebuah kebutuhan dalam mewujudkan keberhasilan kerja. Kerjasama dalam tim akan menjadi suatu daya dorong yang memiliki energi dan sinergisitas bagi individu-individu yang tergabung dalam teamwork. Tanpa kerjasama yang baik tidak akan memunculkan ide-ide cemerlang. Sebagaimana yang dinyatakan Bachtiar (2004) bahwa kerja sama merupakan sinergisitas kekuatan dari beberapa orang dalam mencapai satu tujuan yang diinginkan. Kerjasama akan menyatukan kekuatan ide-ide yang akan mengantarkan pada kesuksesan. 
Tim adalah suatu unit yang terdiri atas dua orang atau lebih yang berinteraksi dan mengkoordinasi kerja mereka untuk tujuan tertentu. Definisi ini memiliki 3 (tiga) komponen. Pertama, dibutuhkan dua orang atau lebih. Kedua, orang-orang dalam sebuah tim memiliki interaksi reguler. Ketiga, orangorang dalam sebuah tim memiliki tujuan yang sama.

Setiap tim maupun individu sangat berhubungan erat dengan kerja sama yang dibangun dengan kesadaran pencapaian prestasi dan kinerja. Dalam kerja sama akan muncul berbagai penyelesaian yang secara individu tidak terselesaikan. Keunggulan yang dapat diandalkan dalam kerjasama pada kerja tim adalah munculnya berbagai penyelesaian secara sinergi dari berbagai individu yang tergabung dalam kerja tim.

Teamwork adalah sekelompok orang yang bekerjasama untuk mencapai tujuan yang sama (Tenner dan Detero dalam Hastuti: 2009). Orang pada semua tingkat organisasi merupakan faktor yang sangat penting dari suatu organisasi dan keterlibatan mereka secara penuh akan memungkinkan kemampuan mereka digunakan untuk manfaat organisasi (Gaspersz dalam Hastuti: 2009). Dengan demikian, setiap orang dalam struktur organisasi perusahaan dengan tujuan tertentu membutuhkan teamwork yang baik untuk mencapai tujuannya itu. Bukti menunjukkan bahwa tim biasanya bekerja lebih baik daripada individu ketika tugastugas yang dilakukan membutuhkan banyak keterampilan, pendapat, dan pengalaman.

Tim memiliki kecakapan untuk berkumpul, menyebarkan, berkumpul kembali, dan membubarkan diri dengan cepat. Misalnya, kira-kira $80 \%$ dari perusahaan Fortune 500 saat ini menempatkan separuh atau lebih karyawan mereka dalam tim. 68\% dari manufaktur kecil di AS juga menggunakan tim di berbagai area produksi mereka (Robbins, 2008: 404). Dapat disimpulkan, teamwork yang efektif memiliki peran yang signifikan bagi perusahaan untuk mencapai tujuannya.
Menurut Hughes (2012:366) teori pembentukan tim harus melewati 4 tahap pembentukan yaitu: tahap forming (pembentukan), tahap storming (goncangan), tahap norming (membangun norma) dan tahap performing (berkinerja). Teori ini tidak dapat diaplikasikan begitu saja kepada masyarakat Indonesia terutama masyarakat suku jawa yang bersifat kolektivistik. Menurut Tjiptono dan Diana (2000:167-168) faktor-faktor penghambat kesuksesan teamwork adalah: Pertama, identitas pribadi anggota tim yaitu tim tidak akan dapat berjalan efektif bila anggotanya belum merasa cocok. Kedua, hubungan antar anggota tim yaitu setiap anggota tim harus saling mengenal dan berhubungan untuk dapat berkerja sama. Dan yang ketiga, identitas dalam organisasi yaitu kecocokan tim dalam organisasi. Teori ini dibuat dan disusun berdasarkan teori barat yang masyarakatnya lebih bersifat individualistik, Berbeda dengan masyarakat Indonesia, terutama masyarakat yang bersuku Jawa yang lebih mengutamakan kebersamaan dan bersifat kolektivistik. Padahal menurut Markus dan Kitayama (1991 dalam Woo: 2009) nilai-nilai dari budaya yang berbeda mempunyai pengaruh terhadap kognitif, emosi, motivasi dan sistem perilaku individu. Oleh sebab itu, diperlukan studi lintas budaya yang membandingkan hubungan-hubungan antara sikap kerja dan perilaku kerja pada level-level budaya yang berbeda di negaranegara yang berbeda.

Menuurut Henderson, Molloy dan Pascual (2001) teamwork adalah faktorfaktor yang berpengaruh pada sistem yang mengatur proses yang menggunakan sumberdaya dan menghasilkan kinerja tertentu. Proses yang mempengaruhi keberhasilan teamwork tersebut adalah indvidual character (skill, pengetahuan dan kecocokan tujuan personal dengan organisasi dan komitmen), task characteristic (kejelasan tujuan, beban kerja), task related (penafsiran situasi, manajemen diri), team related (interaksi internal tim, dukungan), task outcome (kepuasan kerja, ketercapaian 
tujuan) dan team outcame (saling percaya, saling menghargai, visi bersama).

Bergabung dalam sebuah tim, membuat karyawan mempunyai rasa memiliki dan perasaan kebersamaan. Kedekatan yang berlangsung terus menerus dapat menimbulkan kerjasama yang baik di dalam tim itu sendiri dibandingkan kerjasama dengan karyawan yang berbeda tim ( Gibson dkk: 2000). Penelitian Cohen dan Bailey (Judeh, 2011) menyebutkan perusahaan sering mengandalkan teamwork untuk perbaikan terus menerus produk dan jasa, dan juga dari semua fungsi organisasi lannya. Sebagai contoh, beberapa perkiraan mengklaim $80 \%$ dari perusahaan dengan 100 atau lebih karyawan bergantung pada tim dan kelompok untuk pekerjaan yang diberikan. Perusahaan memerlukan kerjasama karyawan untuk kemajuan perusahaannya, oleh karena itu masing-masing anggota mau menerima dan mampu bekerjasama dengan anggota lainnya di dalam tim tersebut (Munandar: 2008).

Berdasarkan penjelasan mengenai teamwork dari berbagai teori di atas, maka juga dapat di ambil sebuah kesimpulan bahwa teamwork karyawan dalam organisasi sangatlah penting, teamwork yang rendah merupakan salah satu hal yang menyebabkan seseorang mudah mengabaikan pekerjaan seperti tidak saling percaya dan mendukung kurang pengetahuan atau skil, saling melempar tanggungjawab dan saling ketergantungan. Padahal dari sisi organisasi sendiri, teamwork sangat bergantung pada anggotanya. Apabila yang melakukan hal ini adalah anggota yang berkualitas dan dianggap dapat membawa kebaikan bagi organisasi, tentu saja kondisi ini akan membawa kerugian tersendiri bagi organisasi. Kondisi di atas sejalan dengan penjelasan dari Lasahido (2007) bahwa teamwork merupakan sarana penggabungan berbagai talenta dan dapat memberikan solusi inovatif suatu pendekatan yang mapan. Selain itu, beraneka ragamnya keterampilan dan pengetahuan yang dimiliki oleh anggota dapat memberi keunggulan yang lebih besar dibandingkan kerja seorang diri. Rentangan keterampilan dan pengetahuan yang dimiliki anggota dan pengawasan diri yang diperlihatkan oleh masing-masing tim memungkinkan untuk diberikan suatu tugas dan tanggungjawab.

Gejala lain yang muncul dari rendahnya teamwork adalah pencapaian target yang terlambat dari waktu yang telah ditetapkan, tidak disiplin dalam menjalankan peraturan, sikap kerja yang tidak mendukung kerja yang positif serta ketidakterbukaan yang dirasakan mengganggu kelancaran kerja dalam organisasi. Hal ini sesuai dengan pendapat Lasahido (2008), menjelaskan bahwa, kerjasama seseorang terhadap organisasinya akan meningkatkan performa kinerjanya sehingga secara signifikan akan terkait dengan keberhasilan kinerja terhadap target yang ditentukan dan pada akhirnya menjadikan tim yang efektif.

Hal-hal yang berkaitan dengan rendahnya teamwork karyawan ini juga terjadi pada PT. X. Sebagai perusahaan yang baru berdiri pada 13 Mei 2015, PT. X hingga saat ini masih berusaha memperbaiki diri agar dapat bersaing dengan perusahaan lainnya dalam hal SDM nya. Karyawan sebagai fungsi pendukung dalam proses ini, diharapkan dapat memberikan kontribusi secara optimal dalam rangka membantu organisasi mencapai tujuannya. Namun pada kenyataannya hal ini sulit terwujud di PT. X. Karyawan terlihat sering datang terlambat, karyawan juga terlihat santai dan tidak mau membantu temannya ketika dalam bekerja, tidak saling percaya satu sama lainnya dan tidak saling mendukung.

Berdasarkan hasil wawancara dengan Direktur pada tanggal 21 Juni 2017, kurangnya teamwork karyawan terhadap organisasi tampak dari permasalahanpermasalahan yang muncul. Adapun permasalahan utama yang dirasakan adalah menurunnya produktivitas kinerja para karyawan, hal ini terjadi pada semua bidang, sehingga mengakibatkan seluruh proses kemajuan perusahaan menjadi lamban 
sehingga sering terjadi kesalahpahaman antara pihak satu dengan pihak yang lainnya. Seperti bagian produksi harus mengecek sekali 2 jam hasil produksi yang sudah selesai diproduksi, namun ini jarang dilakukan, karyawan sehingga kadang terjadi kesalahan, baik bentuk, ukuran, warna, dan lain-lain tidak sesuai dengan pemesanan yang semestinya. Kemudian efek dari permasalahan tersebut menjadi hambatan kepada konsumen. Karna harus didaur ulang dan diproduksi lagi sesuai dengan pemesanan customer. Hal ini terjadi karna tidak adanya kerjasama yang baik antar anggota tim.

Menurut Direktur dalam melaksanakan tugas karyawan seringkali saling melempar tanggung jawab dan saling menyalahkan jika terjadi permasalahan. Selain itu banyak karyawan yang tidak profesional dalam menggunakan waktu seperti datang terlambat, tidak segera melakukan pekerjaan saat masuk jam kerja, pulang lebih awal tanpa ijin, terlambat dalam membuat berbagai laporan, tidak bersedia hadir saat diadakan rapat dan seringkali karyawan bekerja tanpa mengikuti standar operasional prosedur yang telah dibuat. Kemudian karyawan menganggap pekerjaan sebagai rutinitas yang tak perlu ditingkatkan. Direktur mengatakan juga bahwa rata-rata karyawan sebagian adalah masih keluarga perusahaan. Dengan kondisi seperti itu direktur menganggap karyawan merasa tidak akan dipecat, sehingga mereka tidak bekerja secara profesional.

Hasil wawancara ini menunjukkan bahwa karyawan PT. X tidak dapat mengidentifikasi diri dengan peraturan dan nilai-nilai yang sudah ada di perusahaan. Permasalahan yang lain pada PT. X adalah karyawan saling melempar tanggungjawab, tidak peduli dengan rekan kerja yang lain. Karyawan juga sering tidak melakukan koordinasi ketika menyelesaikan pekerjaan sehingga sering terjadi mis komunikasi, misal antara karyawan produksi. Sehingga sering keterlambatan pesanan kepada konsumen. Pada bagian produksi ini karyawan mencakup melakukan pekerjaan dengan bagian pengepakan dan gudang. Bagian divisi yang lain seperti bagian quality control, membiarkan karyawan yang bermasah tanpa melakukan tindakan. Kemudian karyawan juga terlihat santai ketika sebagian dari rekannya sibuk melakukan pengepakan di bagian produksi, dan kadang ada yang terlihat tiduran digudang disaat jam kerja, padahal rekan yang lain sibuk bekerja. sehingga berdampak pada pengiriman barang pada konsumen.

Menurut karyawan, perusahaan kurang memperhatikan kesejahteraan dalam pemenuhan kebutuhan sosial-emosional mereka, seperti kurang adanya pengakuan atau penghargaan terhadap kinerja karyawan, ketidakadilan dalam pemberian upah dan tidak adanya jenjang karir yang jelas, hal ini membuat mereka menjadi enggan memberikan yang terbaik pada organisasi.

$$
\text { Buchholz (2011) menjelaskan }
$$

teamwork karyawan ditempat kerja sangat dipengaruhi oleh beberapa hal yaitu, dipengaruhi oleh nilai-nilai kemanusiaan dan ini sebagai prioritas utama yang harus dipenuhi perusahaan. Selanjutnya teamwork juga dipengaruhi oleh komunikasi dua arah yang komprehensif. Kerjasama dibangun atas dasar kepercayaan dan kepercayaan membutuhkan komunikasi dua arah. Beberapa organisasi bahkan berusaha mengembangkan beberapa program yang menjamin berlangsungnya komunikasi tersebut.

Berdasarkan pendapat Buchholz di atas, diketahui pentingnya komunikasi dua arah (komunikasi interpersonal) dalam membangun teamwork karyawan. Hal ini sejalan dengan pendapat Meyer \& Herscovitch (2001), Yoon \& Thye (2002) dimana salah satu faktor yang dapat mempengaruhi teamwork anggota organisasi adalah kesempatan untuk melakukan interaksi dengan orang lain yang merupakan salah satu cara pemenuhan kebutuhan sosial manusia. Saat kebutuhan ini terpenuhi, maka akan ada usaha dari individu untuk membalas 
kepada organisasi sebagai pihak yang memberi pemenuhan kebutuhan.

Teamwork juga dipengaruhi oleh komunikasi interpersonal ini sesuai dengan pendapat Mohr (dalam Cayono, 2006) bahwa teamwork merupakan kerja secara bersamasama untuk mencapai suatu tujuan bersama dengan maksud individu mencari hasil yang bermanfaat bagi diri sendiri dan bermanfaat bagi semua anggota kelompok lainnya, dengan melibatkan komunikasi interpersonal dari satu bagian ke bagian kelompok yang lain untuk mencapai tujuan bersama.

Komunikasi Interpersonal adalah penyampaian atau penerimaan pesan atau pertukaran makna antara dua orang atau lebih dan membutuhkan umpan balik agar tercapai saling pengertian mengenai apa yang dimaksud. Pelatihan yang merupakan salah satu cara untuk melatih kemampuan komunikasi interpersonal, karena pelatihan merupakan salah satu kegiatan belajar terencana yang dilakukan oleh perusahaan untuk memfasilitasi pengembangan karyawanya.

Idealnya untuk sebuah organisasi menjadi sukses, maka diperlukan teamwork yang baik antara pimpinan dan para bawahannya, seperti staff, crew, teknisi, manager, dan lain-lain. Sehingga tugas yang pada awalnya terasa berat akan menjadi ringan bahkan dapat terselesaikan dengan cepat dan lancar. Hal ini didukung oleh Chen (2004) yang menyatakan bahwa individu yang memiliki komunikasi interpersonal baik akan menciptakan teamwork yang berkualitas karena komunikasi interpersonal merupakan salah satu faktor yang berpengaruh pada pembelajaran yang efektif dalam teamwork.

Dari hal tersebut di atas, komunikasi dari pengirim, penerima pesan adalah pondasi dari komunikasi yang sukses, tetapi juga dapat membuat kesalahpahaman pihak pengirim pesan bisa gagal untuk mengirimkan pesan atau tidak benar untuk mengirimkan pesan yang bermanfaat. Levi (2001) mengatakan bahwa untuk menciptakan teamwork yang baik, komunikasi harus berjalan dengan baik pula. Semakin baik komunikasi yang terjalin maka semakin baik pula teamwork yang tercipta pada organisasi tersebut.

Terbangunnya komunikasi interpersonal yang baik akan membuat iklim organisasi menjadi sangat nyaman. Hal ini tentunya akan membuat konflik yang terjadi bisa diselesaikan dengan cepat, serta karyawan akan lebih merasa nyaman dengan lingkungan kerjanya. Kenyamanan ini akan membuat karyawan termotivasi, sehingga mereka lebih semangat untuk datang tepat waktu dan semangat menyelesaikan pekerjaanya dengan target yang telah ditentukan. Selain jika karyawan sudah merasa nyaman berada di perusahaan, maka tidak akan ada lagi keinginan untuk saling melempar tanggungjawab, tidak saling menghormati, dan akan mendedikasikan diri sepenuhnya untuk perusahaan. Meningkatnya teamwork karyawan di PT.X juga akan mempengaruhi tingkat individualis karyawan, sehingga kondisi perusahaan kembali normal dan tujuan perusahaan dapat dicapai dengan maksimal. Selain itu karyawan yang memiliki teamwork yang tinggi juga akan memiliki keterikatan terhadap peraturan-peraturan perusahaan, dan akan mengerahkan usahanya untuk melakukan yang terbaik demi perusahaan.

Penelitian ini sangat penting karena akan menjawab permasalahan dari fenomena yang diangkat oleh penulis yang telah dituangkan dalam latar belakang di atas. Berdasarkan penelusuran penulis bahwasannya teamwork dalam sebuah organisasi dibentuk melalui komunikasi interpersonal, karena teamwork merupakan suatu keterpaduan antara pemahaman anggota kelompok terhadap proses, tujuan, dan hasil sehingga dibutuhkan komunikasi interpersonal sebagai alat dalam membentuk teamwork. Oleh karena itu penulis tertarik untuk mengangkat sejauh mana komunikasi interpersonal memengaruhi teamwork dalam sebuah organisasi.

\section{TINJAUAN TEORI}




\section{Pengertian teamwork}

Dejanaz (2006) mendefenisikan teamwork adalah sebagai kumpulan individu yang saling bekerja sama dengan saling percaya dan mendukung serta bertanggungawab untuk mencapai suatu tujuan bersama dalam tim.

Fancies and Young (2003) menjelaskan sebuah tim sebagai sekelompok orang giat yang bekerja untuk meraih sasaran umum, di mana bekerja bersama dengan baik dan menikmatinya, dan menghasilkan hasil kualitas tinggi. Johnson and Johnson's (2000) mengartikan sebuah tim adalah seperangkat struktur hubungan interpersonal untuk mencapai tujuan, sementara itu Lanza (1985) mengartikan sebuah tim sebagai sekelompok orang yang bekerja bersama dimana kesuksesan dari setiap individu bergantung pada kesuksesan dari keseluruhan kelompok. Unsur dari definisi tersebut didukung oleh Johnson (2000) siapa yang melihat sebuah tim sebagai beberapa individu yang harus bekerja sama untuk memenuhi suatu misi.

Konsep yang berhubungan erat dari tim dan kelompok sering dibahas secara sinonim, walaupun beberapa pengarang sudah mencoba untuk menjelaskan perbedaannya. Hitt (2002), sebagai contohnya, mendiskusikan definisi dari Dyer bahwa tim adalah koleksi dari orang yang harus mempercayakan pada kerjasama kelompok jika setiap anggota adalah untuk mengalami jumlah maksimum dari kesuksesan dan pretasi tujuan, dan point keluar bahwa tidak semua koleksi dari orang menemukan persyaratan ini. Kazemek dan Albert (1988) berusaha untuk menunjukkan perbedaan di antara karakterisitik kelompok dan tim. Kelompok berfungsi seperti tim yang secara khas memiliki sebuah tujuan yang bersih dan umum. Anggota tim mengerti dimana mereka saling ketergantungan pada kepalsuan lain. Huszczo (1990) mengemukakan pendapat bahwa teamwork merupakan lambungan gagasan dari satu orang ke orang lainnya dan mendatangkan solusi untuk permasalahan kritis, dan organisasi tersebut dimulai dengan mengambil strategi team untuk bekerja dengan kompetisi. Tarkenton (1986) menawarkan sebuah definisi praktis dari tim dengan memfokuskan dalam aktivitas khas dari teamwork. Teamwork memiliki arti bahwa kita mengenali nilai dari para anggota dari tim di luar hanya mengerjakan pekerjaan mereka, bahwa kita ingin mereka menjadi terlibat dalam strategi kita. Ini berarti mendorong level kreativitas dan membuat keputusan lebih lanjut.

Teamwork adalah terdiri dari berbagai macam kelompok kecil orang, setiap orang memiliki derajat yang sama dan penting dalam organisasi. Setiap kelompok berhubungan dengan tiap kelompok lain melalui seorang pemimpin yang ditetapkan (Lau, 1988). Sedangkan menurut Gwyne (1990) teamwork adalah sebuah jalan penting untuk menaikkan efektifitas organisasi. Teamwork adalah sekumpulan keterampilan yang dibutuhkan untuk dikembangkan selama latihan (Levi, 2001). Pendapat lain juga dikemukakan oleh Harry A. Cosgriffe dan Richard T. Dailey (1969) yang menyatakan bahwa teamwork merupakan perbuatan dua orang atau lebih yang bekerja sama ke arah tujuan umum, saling membagi waktu, bakat, dan pengetahuan dan menggunakan metode yang cocok untuk semua anggota tim.

Berdasarkan teori-teori di atas, maka peneliti mengambil kesimpulan bahwa teamwork adalah sekelompok orang yang bekerja sama yang saling berhubungan satu sama lain dan giat bekerja, yang di dalamnya mengandung unsur kepercayaan, kejujuran, tanggung jawab, dukungan, harapan yang tinggi untuk memperoleh tujuan bersama, dan saling memberikan gagasan untuk penyelesaian berbagai masalah yang ada di dalam tim yang bertujuan untuk menaikkan efektifitas organisasi.

\section{Aspek-aspek Teamwork} Hitt (2002) mengutarakan karakteristik teamwork: 
a. Persetujuan umum dalam harapan tinggi untuk tim.

b. Suatu komitmen untuk tujuan umum.

c. Tanggung jawab diasumsikan untuk kerja yang harus dilakukan.

d. Jujur dan komunikasi terbuka.

e. Akses untuk informasi.

f. Iklim kepercayaan.

g. Perasaan umum bahwa seseorang dapat mempengaruhi apa yang terjadi.

h. Dukungan untuk keputusan yang telah dibuat.

i. Suatu pendekatan yang sama-sama untung untuk pengendalian konflik.

j. Suatu fokus pada proses seperti hasil.

Huszczo (1990), seperti Hitt sebelumnya, memberikan daftar karakteristik yang lebih luas dan memiliki penjelasan yang lebih kritis yang dapat membentuk dasar dari penilaian tim yang sistematis, yaitu :

a. Tujuan.

Arah harus jelas dan berhubungan dengan organisasi paling luas. Hal ini juga harus menjadi komitmen dari para anggota.

b. Bakat.

Timharus memiliki bakat dan keterampilan yang melengkapi untuk tugas. Hal ini harus menjadi dorongan anggota untuk perkembangan selanjutnya.

c. Tugas.

Para anggota harus mengerti tugas mereka dalam keikutsertaan untuk kesuksesan tim. Mereka harus memiliki komitmen terhadap tugas-tugas tersebut dan kejelasan tentang kontribusi individu.

d. Pelaksanaan.

Menjalankan pelaksanaan yang efektif dan berguna harus ada di dalam tim. Pertemuan dan perencanaan harus efektif, dan para anggota harus mengetahui bagaimana membuat keputusan, mengatasi masalah, dan membagi serta menerima informasi sebagai sebuah tim.

e. Hubungan Interpersonal.

Para anggota timperlu untuk berhubungan baik dengan satu dengan yang lain, komunikasi dan memecahkan konflik.
Mereka harus saling mendukung satu sama lain. Mereka harus menunjukkan perhatian sehingga level keterampilan semakin tinggi.

f. Penguatan.

Sistem penguatan yang efektif dibutuhkan untuk peningkatan teamwork. Pada level personal, apresiasi harus tegas, dan ini sangat penting untuk pembentukan perilaku tim. Organisasi juga bertanggungjawab untuk penguatan ini.

\section{g. Hubungan external.}

Pembentukan hubungan external dengan lingkungan external harus ada, dan ini harus juga harus menjadi hubungan yang sehat dengan unit lain dalam organisasi itu sendiri. Tim juga perlu untuk meninjau lingkungan tersebut untuk mengenali yang menyangkut ancaman dan kesempatan. Henderseon Molloy (2001) mengidentifikasi 3 karakteristik, dalam kasus ini disebut 'tema', terdapat dalam tipe bekerjanya tim sukses:

a. Anggota-anggota tim memiliki misi dan mengeset tinggi dirinya-harapan dan prestasi. b. Mereka tahu apa yang mereka butuhkan untuk sukses.

c. Penghargaan dibagikan dan anggota merasakan mereka menyokong untuk kesuksesan tim.

Terkait 3 tema di atas ditambahkan kepercayaan, komunikasi, pembuatan keputusan kelompok, dan pembersihan prosedur (faktor telah jelas dalam beberapa daftar di atas). Hal ini diklaim bahwa tema tersebut didasarkan pada temuan penelitian, tapi kita telah diisyaratkan pada masalah metodologis yang dihubungkan dengan penelitian ke dalam tim dan perkembangan mereka, oleh karena itu, karakteristikkarakteristik tersebut seperti ini didasarkan lebih pada pemahaman individu dari kesuksesan tim dan akal sehat yang baik daripada pemeriksaan kaku. Kinerja tim tentu saja harus merencanakan suatu rencana. Ends dan Page (1977) menyokong, 5 aspek utama yang harus secara positif direncanakan :

a. Penetapan tujuan kinerja tim.

b. Merencanakan kerja.

c. Negosiasi peraturan-peraturan. 
d. Penetapan kriteria kinerja, dan

e. Merencanakan umpan balik kinerja.

Muhammad (2005), mendaftarkan lima aspek sebagai kebutuhan untuk perkembangan menjadi sukses dari tim:

a. Tujuan dan arah yang jelas.

Tim butuh tujuan untuk memusatkan untuk memusatkan tujuan mereka dan mengevaluasi kinerja mereka.

b. Pimpinan yang baik.

Pemimpin dibutuhkan untuk mengatur hubungan internal dan eksternal dari tim dan untuk menghadapkan tim ke tujuan mereka.

c. Tugas yang sesuai dengan teamwork.

Tugas harus kompleks, penting, dan menantang sehingga anggota tim memerlukan usaha dan tidak sanggup bekerja individu.

d. Catatan kebutuhan untuk melakukan pekerjaan.

Sumber penghasilan bahwa tim butuh memasukkan kedua sumber alat dan pelatihan dan sumber penghasilan personil.

mendukung

$$
\text { e. Lingkungan organisasi yang }
$$

(2006) mengemukakan beberapa aspek untuk meningkatkan kemampuan teamwork yaitu:

1. Memiliki tujuan yang jelas

2. Memahami tugas dan peran di dalam tim

3. Saling percaya dan mendukung

4. Mampu berpartisipasi di dalam tim

5. Bertanggungjawab terhadap tim

Mulyana (2000) memperhatikan produk baru kinerja tim, diidentifikasi sejumlah faktor mengemudi dimana dapat dihubungkan dengan kinerja efektif, digambarkan dalam terminologi umum sebagai produk sukses baru. Ini adalah sasaran bersih, rangsangan kerja, potensi pertumbuhan profesional, arah dan kepemimpinan, kepercayaan timbal balik dan hubungan interpersonal yang baik, rencana sesuai, komunikasi yang baik di dalam dan di luar tim, stabilitas dan keamanan organisasi, sumberdaya cukup, dan keterlibatan manajemen.

\section{Faktor yang Mempengaruhi Teamwork}

Dejanaz (2006) Faktor-faktor yang mempengaruhi keefektifan sebuah tim atau kelompok kerja merupakan:

\section{a. Tujuan yang jelas}

Kurang jelasnya Tujuan dari suatu kumpulan kerja biasanya menjadi penyebab utama kegagalan kelompok. Saat Tujuan kelompok dikatakan dengan jelas pada masing-masing anggota, maka ada semangat untuk bergerak maju dan keinginan untukbertahan di waktusulit, serta bagaimana menanggulangi halangan-halangan.

b. Struktur tim atau kelompok kerja yang saling mendukung

Untuk menjangkau suatu struktur yang saling mendukung, orang yang bertanggung jawab dalam menyusun tim/kelompok mesti membubuhkan perhatian kepada faedah kelompok, peran anggota tim, tanggungjawab dan tingkat keterampilan anggota, stabilitas dan besar kecilnya suatu kumpulan serta peran kepemimpinan dalam tim/kelompok.

\section{c.Dukungan yang kuat}

Salah satu urusan yang dapat mengakibatkan kegagalan ialah kurangnya dukungan secara organisasi terhadap anggota. Dukungan dalam format pelatihan, pemantauan kerja dan diskusi secara rutin ialah bentuk dukungan yang dibutuhkan dalam kondisi kerja kelompok. Dukungan laksana ini memastikan bahwa masingmasing anggota bias dengan bebas mengeksplorasi kemampuannya dalam memajukan kumpulan secara terkoordinasi, tanpa mengakibatkan hambatan-hambatan yang terlampau berarti.

d. Hubungan internal yang
positif


Banyak kendala serta kelemahan menunjukkan perhatian sehingga merasa anggota dalam tim yang dapat menjadi satu keluarga.

mengakibatkan ketegangan dalam hubungan dan hadir kepermukaan sebagai sikap yang buruk, kekurang percayaan dan perebutan kekuasaan. Maka hubungan internal yang positif sangat mempengaruhi kefektifan suatu tim.

Hackman (2000), mengemukakan beberapa factor mempengaruhi teamwork yaitu:

a. Tujuan dan arah yang jelas

Tim butuh tujuan untuk memusatkan tujuan mereka dan mengevaluasi kinerja mereka.

b. Pemimpin yang baik

Pemimpin dibutuhkan untuk mengatur hubugan internal dan eksternal dari anggota tim dan untuk menghadapkan tim ke tujuan bersama.

c. Tugas yang sesuai

Tugas harus sesuai dan kompleks sehingga anggota tim memerlukan usaha untuk mencapai target yang telah ditentukan tim.

mendukung Lingkungan yang saling

Lingkungan di dalam tim harus saling mendukung, dan anggota harus cukup kuat dan berwibawa untuk mengizinkan anggota tim untuk membuat dan melaksanakan keputusan bersama.

\section{e. Bertanggung jawab}

Setiap tim harus mampu menghadapi tantangan yang diberikan tim, sehingga menjadikan semangat, kebanggaan bagi anggota tim dalam menelesaikan tugasnya.

f. Mampu berkomunikasi dengan baik

Setiap anggota tim harus mampu bekerjasama dengan anggota lainnya, sehingga tidak terjadi munculnya miss komunikasi dengan anggota tim yang lainnya.

g. Hubungan interpersonal

Para anggota tim perlu untuk berhubungan baik dengan satu dengan yang lainnya, komunikasi dan memecahkan konflik. Mereka harus saling mendukung,

disimpulkan bahwa teamwork dapat dipengaruhi beberapa faktor yaitu, hubungan internal yang positif sesama anggota tim, mampu berkomunikasi dengan baik, dimana mereka saling mendukung satu sama lain, saling percaya, bertanggung jawab terhadap tugas yang diberikan tim demi terwujudnya tujuan tim tersebut. Berdasarkan faktorfaktor teamwork tersebut maka peneliti mengkaitkan dengan aspek-aspek komunikasi interpersonal yaitu keterbukaan, empati, sikap mendukung, sikap positif dan kesetaraan.

Komunikasi interpersonal merupakan penyampaian atau penerimaan pesan antara dua orang atau lebih dan membutuhkan umpan balik agar tercapai saling pengertian mengenai apa yang dimaksud. Pelatihan komunikasi interpersonal ini membuat karyawan dapat mengembangkan kompetensinya dalam membangun sikap keterbukaan, empati, sikap mendukung, sikap positif, dan kesetaraan. Dengan terbangunnya lima aspek tersebut karyawan akan bisa membangun sikap saling percaya dan mendukung dalam bekerja sehingga bisa lebih bertanggungjawab dalam menyelesaikan pekerjaan sesuai dengan tujuan tim yang telah ditetapkan. Terbangunnya komunikasi interpersonal yang tinggi akan memiliki kemampuan dalam menjalankan peran kerja dan bertanggungjawab dalam menyelesaikan pekerjaan yang ada di dalam tim.

\section{Pelatihan Komunikasi Interpersonal}

Pelatihan komunikasi interpersonal adalah salah satu program pelatihan yang disusun dengan tujuan mengasah keterampilan seseorang dalam melakukan komunikasi interpersonal sehingga seseorang mempunyai kecakapan sosial dan kecakapan behavioral (Suseno, 2009).

Pelatihan khususnya pelatihan komunikasi interpersonal dalam penelitian ini merupakan metode yang dipilih dan dirancang oleh peneliti guna meningkatkan 
komunikasi interpersonal karyawan PT.X. Pelatihan komunikasi interpersonal dikembangkan berdasarkan aspek komunikasi interpersonal yaitu, menimbulkan rasa keterbukaan, empati, sikap positif dan kesetaraan (Devito, 2006). Alasan dipilihnya pelatihan komunikasi interpersonal untuk meningkatkan teamwork karyawan PT.X adalah, dengan adanya pelatihan komunikasi interpersonal maka kemampuan komunikasi interpersonal karyawan menjadi lebih meningkat. Hal ini akan mencipatakan dukungan sosial sehingga membuat individu merasa lebih nyaman pada sesama anggotatim nya, sehingga teamwork terhadap organisasinya menjadi meningkat.

Pelatihan komunikasi interpersonal disusun dalam enam sesi berdasarkan modifikasi dari modul yang di buat oleh Eky (2016). Sesi pertama menjelaskan tentang konsep atau teori yang mendasari komunikasi interpersonal, seperti pengertian komunikasi interpersonal, fungsi komunikasi interpersonal, aspek-aspek komunikasi interpersonal dan cara melakukan komunikasi interpersonal yang baik terhadap rekan kerja. Sesi ke dua menjelaskan tentang konsep atau teori keterbukaan, pentingnya keterbukaan dalam berkomunikasi dan dilanjutkan dengan permainan jendela Johari. Tujuan dari sesi ini adalah memberikan pemahaman tentang pentingnya sikap terbuka dalam berinteraksi dengan orang lain dan memberikan pemahaman perbedaan persepsi setiap individu dalam merespon stimulus.

Sesi ke tiga dalam pelatihan komunikasi interpersonal menjelaskan tentang konsep atau teori yang mendasari sikap empati dan mengajarkan cara berempati. Pada sesi ini juga diberikan role play untuk mengajarkan cara mendengarkan keluhan dan masukan dari rekan kerja. Tujuan dari sesi ini adalah agar peserta mampu memahami dengan berempati dalam mendengarkan orang lain serta peserta mampu menjadi pendengar yang efektif.

Sesi ke empat menjelaskan tentang konsep atau teori yang mendasari sikap mendukung (suportif), pengertian sikap mendukung dan pentingnya sikap mendukung. Pada sesi ini juga akan diberikan permainan $l$ untuk memberikan pemahaman pada peserta bahwa komunikasi hanya akan bisa berjalan dan berhasil mencapai tujuan jika peserta komunitasnya memiliki visi dan tujuan yang sama dan saling mendukung satu dengan yang lain. Tujuan dari sesi ini adalah memberikan pemahaman pada peserta bahwa setiap tujuan yang akan dicapai harus memiliki unsur komunikasi yang jelas, dengan sikap saling mendukung dari setiap individu maka perusahaan dapat menetapkan rencana dalam pencapaian tujuan.

Sesi ke lima menjelaskan tentang konsep atau teori yang mendasari sikap positif, pengertian sikap positif dan pentingnya sikap positif dalam berkomunikasi dan cara berperilaku yang menunjukkan sikap positif. Pada sesi ini juga akan diberikan permainan give me happines untuk memberikan pemahaman pada peserta bahwa dengan memberikan kata-kata positif bagi orang lain akan dapat membawa pengaruh positif bagi orang lain tersebut. Tujuan dari sesi ini adalah memberikan pemahaman pada peserta bahwa aspek-aspek positif akan mengantarkan individu pada informasi yang positif sehingga individu tersebut menjadi lebih optimis, individu yang memiliki sikap positif akan dapat membantu memberikan semangat dan motivasi pada rekan-rekannya di perusahaan. Sikap positif ini akan mendukung dalam tercapainya interaksi yang efektif, sikap positif ini memiliki dorongan untuk menghargai kepentingan dan keberadaan orang lain

Sesi ke enam dalam pelatihan komunikasi interpersonal menjelaskan tentang konsep atau teori yang mendasari sikap kesetaraan dan mengajarkan perbedaan konfirmasi dengan diskonfirmasi. Pada sesi ini juga diberikan role play untuk mengajarkan cara memahami dan menumbuhkan rasa kesetaraan kepada peserta pelatihan dalam memandang orang lain ketika berinteraksi. Pemahaman dalam 
sesi ini adalah dalam berkomunikasi dengan orang lain, hendaknya penampilan, perbedaan strata seperti kaya, miskin dan jabatan tidak menghambat seseorang untuk dapat memperlakukan orang tersebut sama dengan yang lainnya. Dalam berkomunikasi setiap orang harus memiliki perasaan setara dan sama-sama berharga.

\section{Pengaruh Pelatian Komunikasi} Interpersonal Terhadap Teamwork

Pelatihan khususnya pelatihan komunikasi interpersonal merupakan metode yang dipilih dan dirancang oleh peneliti guna meningkatkan komunikasi interpersonal karyawan PT.X dengan mengembangkan beberapa aspek komunikasi interpersonal yaitu, menimbulkan rasa keterbukaan, empati, sikap positif, saling mendukung dan kesetaraan di antara karyawan (Devito, 2006).

Keterbukaan didefinisikan sebagai kemampuan untuk membuka atau mengungkapkan unsur-unsur kepribadian diri sendiri melalui komunikasi. Kualitas keterbukaan mengacu pada sedikitnya tiga aspek dari komunikasi interpersonal. Pertama, komunikator interpersonal yang efektif harus terbuka kepada orang yang diajaknya berinteraksi, harus ada kesediaan untuk membuka diri mengungkapkan informasi yang biasanya disembunyikan, asalkan pengungkapan diri ini patut. Aspek keterbukaan yang kedua mengacu kepada kesediaan komunikator untuk bereaksi secara jujur terhadap stimulus yang datang.Aspek ketiga menyangkut kepemilikan perasaan dan pikiran dan bertanggung jawan terhadap apa yang telah disampaikan.

Empati merupakan kemampuan seseorang untuk mengetahui dan dapat merasakan apa yang sedang dialami orang lain pada suatu saat tertentu, dari sudut pandang orang lain itu. melalui kacamata orang lain itu. rasa empati dapat diperlihatkan seseorang dari keterlibatan aktif saat mendengarkan orang lain bicara dan memiliki ekspresi wajah dan gerak-gerik yang sesuai, konsentrasi terpusat meliputi komtak mata, postur tubuh yang penuh perhatian, dan kedekatan fisik serta memberikan sentuhan atau belaian yang sepantasnya.

Sikap mendukung merupakan sikap yang ditunjukan dengan tidak memberikan penilaian terhadap penjelasan orang lain, menerima perbedaan dan bersikap fleksibel.Sikap positif dalam komunikasi interpersonal dilakukan dengan dua menyatakan sikap positif pada lawan bicara dan secara positif mendorong orang yang menjadi teman kita berinteraksi. Sedangkan Kesetaraanmerupakan wujud dari pengakuan secara diam-diam bahwa kedua pihak samasama bernilai dan berharga, dan bahwa masing-masing pihak mempunyai sesuatu yang penting untuk disumbangkan.

\section{Aspek-aspek}

komunikasi interpersonal di atas berimplikasi pada perilaku individu dalam proses komunikasi dalam berinteraksi dengan individu lain dalam organisasi. Hal ini akan mencipatakan dukungan sosial sehingga membuat individu merasa lebih nyaman pada sesama anggota timnya. Hal ini juga sejalan dengan penelitian Tarjana (2007), yang menjelaskan bahwa iklim organisasi yang nyaman menjadi acuan dan pedoman untuk pembuatan keputusan, untuk mengerjakan tugas secara efektif dan membangun tekad dan bekerjasama. Selain itu iklin yang nyaman membuat karyawan termotivasi dalam mengejar peluang organisasi dengan penuh semangat, menolong sesama karyawan, menyelesaikan tugas secara kreatif dan penuh dengan ide-ide untuk pembaharuan dan peningkatan kinerja karyawan dalam tim.

Komunikasi interpersonal tidak hanya saling memberi dan menerima informasi, melainkan juga mencerminkan adanya kehangatan, keterbukaan dan dukungan selama terjadinya komunikasi sehingga dapat menimbulkan kepuasan dan kenyamanan dalam bekerja. Dengan adanya keterbukaan dalam berkumunikasi, akan terwujudnya sikap toleransi dan kepekaan yang tinggi antar sesama anggota organisasi sehingga iklim perusahaan menjadi sangat nyaman. hal ini tentunya akan membuat konflik yang terjadi bisa diselesaikan dengan cepat serta karyawan akan lebih merasa nyaman dengan 
lingkungan kerja sehingga mereka lebih semangat untuk datang keperusahaan dan menyelesaikan pekerjaanya dengan target yang telah ditentukan. Beberapa penelitian lain juga menunjukkan bahwa teamwork karyawan terhadap organisasi dipengaruhi oleh hubungan atau interaksi antar anggota tim (Yoon \& Thye, 2002).

Hal ini sejalan dengan penelitian yang dilakukan oleh Farhan (2016) yang menyatakan bahwa adanya hubungan positif antara komunikasi interpersonal dengan teamwork. Dimana korelasi kedua variabel menunjukkan hasil $\mathrm{rxy}=0,513$ dengan taraf signifikan $\mathrm{p}<0,01$. Selain itu penelitian oleh Berliana Sari (2014) dengan hasil bahwa komunikasi interpersonal efektif meningkatkan teamwork karyawan dengan $\mathrm{F}$ $=0,025(\mathrm{p}<0,05)$.

\section{HIPOTESIS}

Hipotesis yang digunakan dalam penelitian ini adalah, "Terdapat perbedaan teamwork pada karyawan PT.X antara sebelum dengan sesudah diberikan pelatihan komunikasi interpersonal pada kelompok eksperimen (KE), dimana tingkat komitmen organisasi karyawan setelah diberi pelatihan komunikasi interpersonal lebih tinggi dibanding tingkat teamwork karyawan sebelum diberikan pelatihan komunikasi interpersonal. "Terdapat perbedaanposttestteamworkkaryawanantara kelompok eksperimen (KE) dengan kelompok kontrol (KK), dimana teamwork karyawan pada kelompok eksperimen (KE) lebih tinggi dibanding kelompok kontrol (KK)".

\section{METODE PENELITIAN}

\section{Identifikasi Variabel Penelitian}

Terdapat dua variabel yang akan diukur dalam penelitian ini, yaitu:

- Variabel independen, yaitu variabel bebas yang dapat mempengaruhi variabel terikat. Variabel independen dalam penelitian ini adalah pelatihan komunikasi interpersonal.

- Variabel dependen, yaitu variabel yang dipengaruhi dan menjadi akibat dari variabel bebas. Variabel dependen dalam penelitian ini adalahteamwork.

2. Subjek Penelitian

Subjek penelitian ini adalah seluruh karyawan leveldivisiproduksi yang terdaftar sebagai karyawan yang memiliki kontrak kerja, berjumlah 20 orang. Alasan dipilihnya karyawan yang memiliki kontrak, karena secara tidak langsung, karyawan tersebut memiliki keterikatan secara legal untuk tetap berada di perusahaan dalam waktu yang cukup lama. Seleksi subjek penelitian dilakukan dengan menyebarkan skala teamwork dan skala komunikasi interpersonal kepada seluruh karyawan produksi. Dari hasil penyebaran dua skala tersebut maka skor setiap karyawan dikategorisasikan menjadi lima tingkat teamwork karyawan dan lima tingkat komunikasi interpersonal karyawan yaitu: ST (Sangat Tinggi), T (Tinggi), S (Sedang), R (Rendah), RS (Rendah Sekali).

3. Desain Penelitian

Jenis penelitian yang digunakan dalam penelitian ini merupakan penelitian eksperimen. Menurut Arikunto (2006), metode penelitian eksperimen adalah salah satu cara untuk mencari hubungan sebab akibat antara dua faktor yang sengaja ditimbulkan oleh peneliti dengan mengeliminasi atau mengurangi faktorfaktor lain yang mengganggu. Secara rinci Latipun, (2004) menjelaskan bahwa, penelitian eksperimen adalah penelitian yang memberikan perlakuan (manipulasi) terhadap variabel penelitian (variabel bebas), kemudian mengamati konsekuensi perlakuan tersebut terhadap objek penelitian (variabel terikat), dengan mengendalikan variabel yang tidak dikehendaki.

Rancangan dalam penelitian ini adalah dengan menggunakan desain eksperimen, 
yaitu Pre-Test Post-Test Contol Group Design. Dalam desain eksperimen ini terdapat beberapa unsur-unsur pokok yaitu:

- Adanya dua kelompok, yaitu kelompok eksperimen (KE) dan kelompok kontrol (KK).

- Adanya Treatment Variabels. Dalam penelitian ini treatment tersebut adalah pelatihan komunikasi interpersonal yang akan diberikan pada kelompok eksperimen (KE).

- Adanya pengukuran untuk melihat perbedaan pretest dan posttest pada kelompok eksperimen (KE) setelah diberikan pelatihan komunikasi interpersonal.

- Adanya pengukuran antara tingkat teamwork karyawan pada kelompok kontrol (KK) dan kelompok eksperimen (KE) setelah pelatihan komunikasi interpersonal.

4. Metode pengumpulan data

Data dalam penelitian ini dikumpulkan dengan menggunakan skala teamwork karyawan dan skala komunikasi interpersonal. Azwar (2005) menjelaskan bahwa skala dapat dicirikan sebagai stimulasi yang berupa pernyataan, artinya stimulus tersebut tidak langsung mengungkapkan atribut yang hendak diukur, melainkan diungkapkan melalui aspek atau indikator perilaku dari atribut yang diukur.

Sebelum digunakan untuk penelitian, skala teamwork karyawan dan skala komunikasi interpersonal ini terlebih dahulu akan di ujicobakan, hal ini bertujuan untuk menguji validitas dan reliabilitas alat ukur tersebut. Uji coba alat ukur ini juga bertujuan untuk menyeleksi aitem-aitem mana saja yang valid dan reliabel agar dapat digunakan dalam penelitian. Uji coba alat ukur ini akan dilakukan kepada 20 karyawan produksi anak cabang dari PT.X yang berada di Bantul.

Berdasarkan hasil uji coba skala teamwork, maka diketahui validitas skor tiap-tiap aitem bergerak antara 0,002 hingga 0,629, sedangkan hasil uji reliabilitas seluruh aspek setelah ujicoba adalah 0,885.Terdapat 10 aitem yang gugur dari 36 aitem yang disebarkan, yaitu aitem favorable nomor 3, $5,9,20,22,28,33$ pada aspek memahami peran tugas dalam tim, memiliki tujuan, mampu berpartisipasi, danberadaptasi. Aitem unfavorable nomor 2,15,29 pada aspek memilikitujuan,

bertanggungjawabdanmemahamiperandantug asdalamtim. Sedangkan Berdasarkan hasil uji coba skala komunikasi interpersonal, maka diketahui validitas skor tiap-tiap aitem bergerak antara 0,095 hingga 0,843, sedangkan hasil uji reliabilitas seluruh aspek adalah 0,865 .Terdapat 16 aitem yang gugur dari 40 aitem yang disebarkan, yaitu aitem favorable nomor $5,12,13,15$, $24,25,31,32,33$ dan aitemunfavorable nomoraitem $6,9,19,20,26,27,40$ pada aspek sikap mendukung, aspek sikap positif,aspek kesetaraan,

keterbukaandanaspekempati

\section{A. HASIL DAN PEMBAHASAN}

Terdapat dua uji hipotesis dalam pelitian ini, yang pertama bertujuan untuk melihat apakah terdapat perbedaan teamwork antara kelompok eksperimen (KE) yang diberi pelatihan komunikasi interpersonal dengan kelompok kontrol (KK) yang tidak diberi pelatihan komunikasi interpersonal, uji hipotesis ini menggunakan uji Mann Whitney. Adapun hasil dari uji Mann Whitney menunjukkan nilai $Z=-3,790$ pada $\mathrm{p}<0,01$. Hal ini berarti ada perbedaan teamwork yang signifikan antara kelompok eksperimen dan kelompok kontrol. Perbedaan tersebut dapat dilihat pada ranking kelompok eksperimen (KE) 15,50 dan kelompok kontrol (KK) 9,50. Berdasarkan hasil tabel di atas maka dapat di ambil kesimpulan, bahwa skor teamwork pada kelompok eksperimen (KE) lebih tinggi dibanding skor teamwork karyawan pada kelompok kontrol (KK). Selisih perbedaan rata-rata tersebut adalah 6 poin, dengan demikian hipotesis pertama diterima.

Sedangkanhipotesis yang kedua bertujuan untuk melihat perbedaan teamwork karyawan antara sebelum dengan sesudah diberikan pelatihan komunikasi interpersonal pada kelompok eksperimen (KE), uji hipotesis ini 
menggunakan uji Wilcoxon. Hasil statistik dari uji Wilcoxon, diperoleh nilai $\mathrm{Z}=-3,827$ pada $\mathrm{p}<0,01$. Artinya ada perbedaan tingkat teamwork karyawan PT.X antara sebelum diberikan pelatihan komunikasi interpersonal dengan setelah diberikan pelatihan komunikasi interpersonal, dengan demikian hipotesis kedua diterima.

Berdasarkan penjelasan dari hasil penelitian, diketahui bahwa pelatihan komunikasi interpersonal dapat meningkatkan teamwork karyawan PT.X. Peningkatanteamwork pada karyawan PT.X ini tidak hanya didapat dari analisis statistik saja, namun juga diperoleh dari evaluasievaluasi yang peneliti lakukan. Selain itu penelitian ini juga didukung oleh penelitian lainnya yang menunjukkan bahwa pelatihan komunikasi interpersonal efektif untuk meningkatkan teamwork pada karyawan.

Hasil penelitian Okta

membuktikan bahwa komunikasi interpersonal dapat efektif untuk meningkatkan teamwork. Kelompok yang diberi pelatihan komunikasi interpersonal menunjukkan peningkatan teamwork secara signifikan. Teamwork karyawan dapat ditingkatkan dengan menggunakan metode pelatihan sebagai sarana belajar melalui pengalaman langsung. Hasil penelitian ini juga membuktikan bahwa penelitian Penelitian Farhan (2016) dengan judul hubungan antara komunikasi interpersonal dengan teamwork pada karyawan, Berdasarkan hasil penelitian ini dinyatakan bahwa adanya hubungan positif antara komunikasi interpersonal dengan teamwork. Hal ini sejalan dengan hasil penelitian yang peneliti lakukan peneliti, dimana komunikasi interpersonal memiliki pengaruh terhadap peningkatan teamwork karyawan.

Hasil penelitian ini juga membuktikan bahwa penelitian Muhammad Iqhsanul (2011) mengenai pengaruh komunikasi interpersonal terhadap komitmen organisasi. Hasil penelitian Muhammad Iqhsanul (2011) menjelaskan bahwa komunikasi interpersonal berpengaruh positif terhadap teamwork dan ketika pola komunikasi interpersonal karyawan di organisasi dipersepsikan baik maka akan menciptakan teamwork karyawan yang tinggi. Hal ini sejalan dengan hasil penelitian yang peneliti lakukan, dimana dengan diberikannya pelatihan komunikasi interpersonal terbukti teamwork karyawan menjadi semakin meningkat.

Aspek-aspek komunikasi interpersonal seperti keterbukaan, empati, sikap positif dan saling mendukung serta membangun sikap kesetaraan berimplikasi pada perilaku individu dalam proses komunikasi dalam berinteraksi dengan individu lain dalam tim. Hal ini akan mencipatakan dukungan sosial sehingga membuat individu merasa lebih nyaman pada sesama anggota timnya, sehingga teamwork terhadap timnya menjadi lebih tinggi (Novianti, 2008). Hal ini juga sejalan dengan penelitian Harjana (2007), yang menjelaskan bahwa iklim organisasi yang nyaman menjadi acuan dan pedoman untuk pembuatan keputusan, untuk mengerjakan tugas secara efektif dan membangun tekad dan teamwork karyawan. Selain itu iklim yang nyaman membuat karyawan termotivasi dalam mengejar peluang organisasi dengan penuh semangat, menolong sesama karyawan, menyelesaikan tugas secara kreatif dan penuh dengan ide-ide untuk pembaharuan dan peningkatan kinerja karyawan dalam tim.

Alur perubahan perilaku yang terjadi pada penelitian ini diawali dengan cara memberikan materi-materi tentang komunikasi interpersonal. Dengan memberikan materi-materi tentang komunikasi interpersonal akan meningkatkan pengetahuan karyawan tentang cara berkomunikasi interpersonal dengan rekan di dunia kerja. Selanjutnya dengan adanya pengetahuan akan menimbulkan keyakinan bahwa komunikasi interpersonal dengan rekan dalam bekerja harus dilakukan dengan benar, jika tidak tentu akan menimbulkan banyak kesalah pahaman dalam pelaksanaan tugas, dan terjadi konflik-konflik sehingga menimbulkan ketidaknyamanan dalam bekerja. Hal ini sejalan dengan pengertian pelatihan komunikasi interpersonal yang 
dikemukakan oleh Suseno (2009), bahwa komunikasi interpersonal adalah salah satu program pelatihan yang disusun dengan tujuan mengasah keterampilan seseorang dalam melakukan komunikasi interpersonal sehingga seseorang mempunyai kecakapan sosial dan kecakapan behavioral yang pada akhirnya hal ini akan mempengaruhi perilaku karyawan untuk memperbaiki cara dalam berkomunikasi dengan rekan kerjanya. melalui komunikasi interpersonal yang seperti ini membuat individu merasa lebih nyaman pada sesama anggota organisasinya, sehingga teamwork terhadap timnya menjadi lebih tinggi (Novianti, 2008).

\section{B. HASIL DAN PEMBAHASAN}

Terdapat dua uji hipotesis dalam pelitian ini, yang pertama bertujuan untuk melihat apakah terdapat perbedaan teamwork antara kelompok eksperimen (KE) yang diberi pelatihan komunikasi interpersonal dengan kelompok kontrol (KK) yang tidak diberi pelatihan komunikasi interpersonal, uji hipotesis ini menggunakan uji Mann Whitney. Adapun hasil dari uji Mann Whitney menunjukkan nilai $\mathrm{Z}=-3,790$ pada $\mathrm{p}<0,01$. Hal ini berarti ada perbedaan teamwork yang signifikan antara kelompok eksperimen dan kelompok kontrol. Perbedaan tersebut dapat dilihat pada ranking kelompok eksperimen (KE) 15,50 dan kelompok kontrol (KK) 9,50. Berdasarkan hasil tabel di atas maka dapat di ambil kesimpulan, bahwa skor teamwork pada kelompok eksperimen (KE) lebih tinggi dibanding skor teamwork karyawan pada kelompok kontrol (KK). Selisih perbedaan rata-rata tersebut adalah 6 poin, dengan demikian hipotesis pertama diterima.

Sedangkanhipotesis yang kedua bertujuan untuk melihat perbedaan teamwork karyawan antara sebelum dengan sesudah diberikan pelatihan komunikasi interpersonal pada kelompok eksperimen (KE), uji hipotesis ini menggunakan uji Wilcoxon. Hasil statistik dari uji Wilcoxon, diperoleh nilai $\mathrm{Z}=-3,827$ pada $\mathrm{p}<0,01$. Artinya ada perbedaan tingkat teamwork karyawan PT.X antara sebelum diberikan pelatihan komunikasi interpersonal dengan setelah diberikan pelatihan komunikasi interpersonal, dengan demikian hipotesis kedua diterima.

Berdasarkan penjelasan dari hasil penelitian, diketahui bahwa pelatihan komunikasi interpersonal dapat meningkatkan teamwork karyawan PT.X. Peningkatanteamwork pada karyawan PT.X ini tidak hanya didapat dari analisis statistik saja, namun juga diperoleh dari evaluasievaluasi yang peneliti lakukan. Selain itu penelitian ini juga didukung oleh penelitian lainnya yang menunjukkan bahwa pelatihan komunikasi interpersonal efektif untuk meningkatkan teamwork pada karyawan.

$$
\text { Hasil penelitian Okta }
$$

membuktikan bahwa komunikasi interpersonal dapat efektif untuk meningkatkan teamwork. Kelompok yang diberi pelatihan komunikasi interpersonal menunjukkan peningkatan teamwork secara signifikan. Teamwork karyawan dapat ditingkatkan dengan menggunakan metode pelatihan sebagai sarana belajar melalui pengalaman langsung. Hasil penelitian ini juga membuktikan bahwa penelitian Penelitian Farhan (2016) dengan judul hubungan antara komunikasi interpersonal dengan teamwork pada karyawan, Berdasarkan hasil penelitian ini dinyatakan bahwa adanya hubungan positif antara komunikasi interpersonal dengan teamwork. Hal ini sejalan dengan hasil penelitian yang peneliti lakukan peneliti, dimana komunikasi interpersonal memiliki pengaruh terhadap peningkatan teamwork karyawan.

Hasil penelitian ini juga membuktikan bahwa penelitian Muhammad Iqhsanul (2011) mengenai pengaruh komunikasi interpersonal terhadap komitmen organisasi. Hasil penelitian Muhammad Iqhsanul (2011) menjelaskan bahwa komunikasi interpersonal berpengaruh positif terhadap teamwork dan ketika pola komunikasi interpersonal karyawan di organisasi dipersepsikan baik maka akan menciptakan teamwork karyawan yang tinggi. Hal ini sejalan dengan hasil penelitian yang peneliti lakukan, dimana dengan diberikannya pelatihan komunikasi interpersonal terbukti teamwork karyawan 
menjadi semakin meningkat.

Aspek-aspek komunikasi interpersonal seperti keterbukaan, empati, sikap positif dan saling mendukung serta membangun sikap kesetaraan berimplikasi pada perilaku individu dalam proses komunikasi dalam berinteraksi dengan individu lain dalam tim. Hal ini akan mencipatakan dukungan sosial sehingga membuat individu merasa lebih nyaman pada sesama anggota timnya, sehingga teamwork terhadap timnya menjadi lebih tinggi (Novianti, 2008). Hal ini juga sejalan dengan penelitian Harjana (2007), yang menjelaskan bahwa iklim organisasi yang nyaman menjadi acuan dan pedoman untuk pembuatan keputusan, untuk mengerjakan tugas secara efektif dan membangun tekad dan teamwork karyawan. Selain itu iklim yang nyaman membuat karyawan termotivasi dalam mengejar peluang organisasi dengan penuh semangat, menolong sesama karyawan, menyelesaikan tugas secara kreatif dan penuh dengan ide-ide untuk pembaharuan dan peningkatan kinerja karyawan dalam tim.

Alur perubahan perilaku yang terjadi pada penelitian ini diawali dengan cara memberikan materimateri tentang komunikasi interpersonal. Dengan memberikan materi-materi tentang komunikasi interpersonal akan meningkatkan pengetahuan karyawan tentang cara berkomunikasi interpersonal dengan rekan di dunia kerja. Selanjutnya dengan adanya pengetahuan akan menimbulkan keyakinan bahwa komunikasi interpersonal dengan rekan dalam bekerja harus dilakukan dengan benar, jika tidak tentu akan menimbulkan banyak kesalah pahaman dalam pelaksanaan tugas, dan terjadi konflik-konflik sehingga menimbulkan ketidaknyamanan dalam bekerja. Hal ini sejalan dengan pengertian pelatihan komunikasi interpersonal yang dikemukakan oleh Suseno (2009), bahwa komunikasi interpersonal adalah salah satu program pelatihan yang disusun dengan tujuan mengasah keterampilan seseorang dalam melakukan komunikasi interpersonal sehingga seseorang mempunyai kecakapan sosial dan kecakapan behavioral yang pada akhirnya hal ini akan mempengaruhi perilaku karyawan untuk memperbaiki cara dalam berkomunikasi dengan rekan kerjanya. melalui komunikasi interpersonal yang seperti ini membuat individu merasa lebih nyaman pada sesama anggota organisasinya, sehingga teamwork terhadap timnya menjadi lebih tinggi (Novianti, 2008).

\section{KESIMPULAN}

Berdasarkan hasil analisis data dan pembahasan sebelumnya, maka dapat disimpulkan bahwa terdapat perbedaan nilai posttest teamwork karyawan pada Kelompok eksperimen dengan kelompok kontrol dimana kelompok eksperimen memiliki tingkat teamwork karyawan yang lebih tinggi dari pada kelompok kontrol, hasil ini menunjukkan bahwa pelatihan komunikasi interpersonal dapat meningkatkan teamworkkaryawan pada PT.X.

Selain itu juga terdapat perbedaan teamwork pada kelompok eksperimen antara sebelum dengan sesudah diberikan pelatihan komunikasi interpersonal, dimana tingkat teamwork setelah diberikan pelatihan komunikasi lebih tinggi dibanding sebelum diberikan pelatihan komunikasi interpersonal. Peningkatan ini disebabkan oleh intervensi pelatihan komunikasi interpersonal yang diberikan dapat meningkatkan pengetahuan komunikasi interpersonal, sehingga mengakibatkan meningkatkan teamwork karyawan pada kelompok eksperimen. Berdasarkan keseluruhan pembahasan dan evaluasi pelatihan maka dapat disimpulkan bahwa pelatihan komunikasi interpersonal dapat meningkatkan teamwork karyawanpada PT.X.

1. Saran

a. Saran untuk organisasi

Pelatihan komunikasi interpersonal dalam penelitian ini terbukti mampu meningkatkan teamwork pada karyawan di PT.X. Oleh karena itu, pelatihan komunikasi dapat dijadikan 
Abdul Aziz, Pelatihan Komunikasi Interpersonal.... 57

salah satu intervensi dalam mengatasi permasalahan yang berkaitan dengan rendahnya teamwork karyawan di PT.X.

b. Saran untuk penelitian selanjutnya

1) Penelitian selanjutnya dapat mempertimbangkan pemberian perlakuan placebo (perlakuan yang sifatnya netral) kepada kelompok kontrol (KK) pada saat yang bersamaan dengan pelatihan yang diberikan pada kelompok eksperimen.

2) Penelitian selanjutnya diharapkan mempertimbangkan waktu penyelengaraan pelatihan, seperti diselenggarakan dalam lama waktu yang lebih panjang (2 hari) agar peserta tidak terlalu lelah atau bosan.

Peneliti selanjutnya diharapkan dapat melakukan evaluasi hasil, dengan tujuan agar dapat mengukur dampak atau hasil akhir dari sebuah pelatihan seperti tercapainya target dan meningkatnya kinerja karyawan.

\section{DAFTAR KEPUSTAKAAN}

- Agustina (2002). Hubungan Antara Efektivitas Komunikasi Interpersonal dengan Kenakalan Remaja Pada Siswa SMA Azwar, S. (2006).Reliabilitas dan validitas. Yogyakarta: Pustaka Pelajar.

Azwar, S. (2010).Penyusunan skala psikologi. Yogyakarta: Pustaka Pelajar.

Azwar, S. (2012).Metode penelitian. Yogyakarta: Pustaka Pelajar.

Bachtiar (2004).Pelatihan komunikasi interpersonal untuk meningkatkanteamworkkaryawan PT.

TirtaSemarang.Tesis.Universitas Gadjah Mada Yogyakarta.

Chen, S.G., D.E, What Makes Teamwork, Group Effectiveness Research from the Shop to the Executive Suite, Journal of Management, Vol23:3, 199.

Dejanaz, S., Dowd, K,. 2006. Interpersonal skilils in Organization. New York: Mc Graw-Hill Companies.
Dessler. (2009). Managing organization in era of change. Florida: The Dryden Press.

Devito. (2011). Komunikasi antar manusia: edisi kelima (terjemah). Pamulang: Karisma Publishing Gruop.

Dyer, W.G. (2001). Teamwork:Curent Issues and New Alternative, New York: Addison-Wesley Series on Organization Develovement.

Fencies, Young (2003). Employeeorganization linkages: The psychology of Teamwork, absenteeism, and turnover. New York: AcademicPress.

Harjana.(2007). Iklim komunikasi keorganisasian.Jurnal Komuni.asi, Vol: 167177

Hitt (2002). Antecendent to boundaryspanner.Perceived organizationalsupport.Journal of Managerial Psychology, 166-128.

Hastuti. (2009). Kinerja Manajerial: Hasil Kerja tim dan perbaikan Berkesinambungan. Jurnal Riset Ekonomi dan Bisnis Vol.9 No.1, Maret organizational support.Journal of Managerial Psychology, 166-128.e

Henderson, Molloy. (2001). Implementation of the Teamwork Skills Inventory Among Adolescens, Tesistidak diterbitkan, Arizona State University, 2010.

Hit. (1998). An introduction to industrial and organizational psychology (6th ed). New York: Mc. Millan Publishing Company.

Hughes,(2012). Leadership. Edisi 7. Penerbit Salemba Humanika. Jakarta.

Ivancevich, J,. Konopaske., \& bodie,. Perilaku dan Manajemen Organisasi. Jakarta: Erlangga.

Jhonsons. (2000). The measurement of organizational Teamwork.Journal of Vocational Beahvior, Vol.14: 224 247.

Johlke \& Duhan. (2002). Antecendent to boundary-spanner. Perceived 
organizational support. Journal of Managerial Psychology, 166-128.

Judeh, M. 2011. An Examination of the Effect of Employee Involvementon

Teamwork Effectivenes: An Empirical Study. International Journal of Business and Management, Vol.6, No.9.

Kitayama, Woo. (2009). Teori komunikasi antar pribadi. Jakarta: Kencana Prenada Media Group.

Kemp (2006). Learning about Teamwork in an Online Study Environment.

Levi. (2001). Komunikasi \& public relations. Bandung: Pustaka Setia.

Lisahido. (2001). Managing organization in era of change. Florida: The DrydenPress.

Muhammad. (2005). Teori komunikasi antar pribadi. Jakarta: Kencana Prenada Media Group.

Mulyana. (2000). Pengantar ilmu komunikasi. Jakarta: PT. Raja Grafindo.

Mohammad. (2009). Komunikasi internasional perpektif jurnalistik. Bandung: Simbiosa Rekatama Media

Prasetyo. (2008). Metode penelitian kuantitatif: teori dan aplikasi. Jakarta: PT. Raja Grafindo Persada.

Robbins, S.P. (2008).Organization behavior.concepts, controversies, applications. Edisi ke 7. New Jersey: Prentice Hall.

Robbins, S. P. (2008). Perilaku organisasi (Vol 1-2). Jakarta: Salemba Empat.

Sugiyono. (2011). Metode penelitian kuantitatif, kualitatif dan $R \& D$. Bandung: IKAPI.

Sugiyono.(2015). Statistika untuk penelitian. Bandung: Alfabeta.

Suseno.(2009). Pengaruh pelatihan komunikasi interpersonal terhadap efikasi diri sebagai pelatih pada mahasiswa.Jurnal Intervensi Psikologi, 1 (1).

Suranto. (2011) Hubungan antara kepuasan komunikasi dengan Teamwork pada karyawan rumah sakit Muhammadiyah Yogyakarta.Tesis. Universitas Gajah Mada Yogyakarta.

Widjaja. (200). Studi kasus iklim pengaruh organisasi, komunikasi dan kejasama tim terhadap perilaku individu dosen negeri di Banjarmasin. Polibis Jurnal Ekonomi dan Bisnis, 6 (2), 8890.

Widjaja.(2010). Komunikasi dan hubungan masyarakat. Jakarta: PT. Bumi Aksara.

Widoyoko.(2012). Teknik penyusunan instrumen penelitian.Yogyakarta: Pustaka Pelajar.. 